\title{
THE SIGNIFICANCE OF LOCAL FOOD IN THE CONSUMPTION OF MODERN CONSUMER
}

\author{
Lienite Litavniece $^{1 *}$, Inese Silicka ${ }^{1}$, Iveta Dembovska ${ }^{1}$, Rasma Tretjakova $^{2}$ \\ ${ }^{1}$ Faculty of Economic and Management, Rezekne Academy of Technologies, Atbrivosanas aleja 115, Rezekne, Latvia, \\ e-mail: litavniece@ivbox.lv \\ ${ }^{2}$ Faculty of Engineering, Rezekne Academy of Technologies, Atbrivosanas aleja 115, Rezekne, Latvia
}

\begin{abstract}
With time changing, consumer diet changes as well. Food industry trends show that people increasingly choose the local food. This study aims to explore the local food choices and use by modern consumers. The researchers have conducted the survey to find out the peoples' understanding of different types of food, such as functional foods, novel foods, ecological, etc. The aim of the survey was to explore how often the modern consumers choose the local food and what is their attitude to it. The survey was organized in the beginning of 2017, and more than five hundred respondents were surveyed. The survey data indicate that the consumers when buying food pay attention to food quality, expiry date, and price. The respondents regularly buy food from the local domestic food producers. Consumer behaviour is affected by the economic development and education level in the country. If education level increases, demand for the quality food - in this case the local food - will increase as well.
\end{abstract}

Keywords: local food, local food producer, consumer behaviour, food logistic.

\section{Introduction}

Institutions and economy affect the market development. Food sector is one of the largest industrial sectors in Latvia (food industry comprises about $20 \%$ of the total processing industry's Gross Domestic Products (GDP) (Zinojums par...., 2016). The economic processes determine how the food delivery systems are designed, what decisions are passed at the political level to promote development of the market favourable for the local products. An important aspect is the market and business regulative framework, for instance, restrictions regarding distribution of genetically modified organisms, use of agricultural chemicals, etc., as well as restrictions regarding planning of the land use, such as use of agricultural land, and allotment areas in the city. Food policy and legislative base to the large extent depends on the global policy, particularly the European Union's policies in areas of agriculture, industry, and consumer rights.

In the Maslow's pyramid of needs, food is located at the level of basic needs, nevertheless, although the food is a basic human need, its choice nowadays is determined by various factors or combination of factors, which is not always rational, but often can be irrational. Therefore, an individual choosing food and satisfying personal needs takes into account both food's impact on the health, its quality, balance, safety, price, availability, etc.

According to the Institute of Food Research, there is a growing number of buyers in the European Union countries considering healthiness as a main criterion for choice and purchase of foodstuff (Vaarst, Hovi, 2004). Along with stabilisation of economic situation in Latvia and increase of the household income, this trend gradually will become relevant in Latvia as well (Jemeljanovs, 2013).

Currently, increasing role of the local foods is enhanced by the communities' willingness to develop the local economic activities and to maintain the local identity; however, they are hold back by the lack of regulatory framework, which does not even define a term "local food".

The research aims to explore the choices of local food and its consumption by the modern consumers.

Modern (nowadays) consumer characterize: around-theclock-shopping, consumers are in control, omnichannel shopping, content consumers, global experience, collaborators and social sharers (Bolen, 2016).

\section{Materials and Methods}

Scientific (article) and practical (law) information was used in the research.

A set of general scientific methods (monographic, logical constructive, graphic) and sociological research method (survey) were used to carry out the research.

Within the research, a questionnaire was developed to assess the extent the population of Latgale planning region (Latvia) consume local foods. The survey was conducted in January - February, 2017 by internet. Altogether 504 valid questionnaires were collected. According to the Central Statistical Bureau data, the number of permanent residents of the Latgale region was 276358 in 2016 (Centrala Statistikas..., 2016). Applying a simple random sampling method, it was calculated that the required number of respondents, in order to confirm the data obtained is reliable (with probability of 95\%) and represents the general sample, is 384. Since, in fact, larger number of respondents (504) was surveyed, it can be stated that the data obtained with a probability of $95 \%$ demonstrates the extent to which the local population consumes the local foods (Raosoft, 2004).

The aim of questionnaire was to examine consumers about their behaviour for choice food and knowledge about their consumption of local food. Questionnaire had 23 questions about consumer behaviour and their attitude to the local food and also about quality and consumer knowledge's about new food, functional food etc. Results of these questions (quality, consumer knowledge's etc.) authors do not use in this article because these results authors will use in other research. 
Authors use SPSS for data processing and use descriptive statistics, correlations analyse, frequencies. Respondents can give more than one answer for some questions and according it the results were calculated for each answer as for separate question.

Characteristics of the survey's participants: $65.7 \%$ of the respondents are women and $34.3 \%$ - men; $35.8 \%$ of the respondents are under the age of $24,16.3 \%-25-35$, $20.1 \%$ - 36-45, 19.1\% - 46-60, 8.7\% - 61 and more. $47.0 \%$ of respondents are employees, $31.7 \%$ - students, pensioners $\quad(6.3 \%), \quad$ employers $\quad(6.0 \%)$, housewives / men (5.8\%), and unemployed (2.8\%). $43.8 \%$ of the respondents have graduate (higher) education, $29.4 \%$ - secondary education (since $31.7 \%$ of the respondents are students), 20.0\% - vocational education, and $6.8 \%$ - primary education. Most of the respondents $(64.1 \%)$ reside in cities, $26.3 \%$ - in villages, and $9.6 \%$ - in farmsteads. It is essential that $67.5 \%$ of the respondents have their own backyard farm; hence, it is evidence in favour of the self-produced foodstuff, that is, the local food with a known origin.

\section{Results and Discussion}

The concept "local food" is being used more often and more broadly, though, there is no a single and official definition of it (Litavniece, Silicka 2016).

Many researchers have carried out scientific and practical studies on the local foods (i.e., Abate, 2008; Anderson, 2009; Aurier et al., 2005; Bahram, 2003; Best et al., 2009; Brown et al., 2008; Carpio et al., 2009; Futamura, 2007; Hughes, 2007, etc.).

This study particularly is focused on the concept of "local food". This concept hasn't one official definition what is acceptable in the different countries. According it, definition of "local food" usually is explained as combination of two essential aspects:

- Geographical (Hughes, 2007; Best et al., 2009; Bahram, 2003; Aurier et al., 2005; Abate, 2008; Anderson, 2007). In this concept, a distance between the producer and consumer dominates (in line with the above mentioned interpretation of the "food of local identity").

- Characteristics of social and supply chains (Futamura, 2007; Carpio et al., 2009; Brown et al., 2008; Aurier et al., 2005; Abate, 2008; Anderson, 2007). Advantage of short supply chains is related with the relationship between the consumer and product seller. Short supply chains are characterized by a spatial proximity, in this case the food is produced and marketed specifically for this region, and consumers are aware about the local characteristics of the product (Litavniece, Silicka 2016).

In Latvia, the local food distribution channels can be divided using V. Praude's typology of local grocery market participants (Praude, 2011) as follows.

- Business to Customer (B2C) - the company's products are sold to the final consumers. For example, the domestic food markets, direct sales communities.
- Business to Business (B2B) - company sells the product to another company, for example, to the retail stores (Rimi, Uga, Satys), restaurants, cafes, and other catering companies, guest houses.

- Business to Government (B2G) - company sells products to the state and municipal enterprises, for example, green procurement program, programs "Skolas piens" ('School Milk') and "Skolas auglis" ('School Fruit'). Healthy nutrition aspect characterizes these programs.

- Every year, the European Union Member States spend an average $19 \%$ of GDP for public procurement purposes. In Latvia, public procurement accounts $17 \%$ of GDP. Such an effect on the goods and services market is significant; therefore, by including the environmental requirements in the public procurement (when implementing green public procurement) it is possible not only to promote increase of the share of environment-friendly goods and services in the market, but also to achieve financial and social improvements (EK, 2011). Thus, green public procurement can be used as a "critical mass" for the environment friendly products' market development (Testa et. al 2012).

The current consumption trends and the local foodstuff characterize a quality of contemporary life. Quality of life, in turn, is no longer just a simple set of social indicators, as Dutch scientist F. Oort (2005) states, rather it is a complex concept including "objective" and "subjective" indicators mutually interacting in different areas of life. The authors of the study consider that it has not changed even now. Alike the society, the concept of life quality changes and evolves.

The World Health Organization defines life quality as "an individual's perception of personal life position in the context of culture and value system in which the individual lives and is linked to his/her goals, expectations, standards, and concerns. This is a broad concept, which is affected in a complex way by individual's physical health, psychological state, personal beliefs, social relations, and the most important environmental factors". The Ministry of Health has developed the Public Health Guidelines for 2014-2020, including three prerequisites of healthy nutrition identified in the Public Health Guidelines of the previous periods (Sabiedribas veselibas ..., 2014):

$\circ$ food quality and safety;

○ balanced nutrition;

- availability of the food based on the local agriculture for every citizen.

To be able to analyse and evaluate role of the local products in nutrition of the consumers, it is necessary to understand the overall tendencies in food consumption. Structure of the consumption expenditure is one of the indicators characterizing the material welfare of the society. The main priorities of the consumption expenditure for the last two years are - food, housing, and transport (Majsaimniecibu..., 2016). 
In the households, $1.7 \%$ more on food and non-alcoholic beverages was spent in 2015 compared to 2014, which could partly be explained by wider use of public catering services, as well as by decline of food prices by $1.3 \%$. Consequently, at reference prices, the expenditure on food and non-alcoholic beverages increased by $3.0 \%$. The households spend three-quarters $(76 \%)$ of the total food expenditure buying food in the retail stores, $8.7 \%$ buying food in kind, and $14.8 \%$ is spent for public catering. Along with improvement of economic situation, the households' expenditure for catering services continues to increase. Namely, these expenditures have increased in average by $11 \%$ in 2015 , compared to 2014. In 2015, the households spent more on such foodstuff as meat and meat products. (Majsaimniecibu..., 2016)

Though, the structure of consumption is changing. Consumption of non-alcoholic beverages and liquors, fruits, poultry and meat products increases. Thus, the authors conclude that the changes in division of work and leisure, as well as an increasing intensity of life leave the impact on the food choices. These trends contribute to the consumption of semi-processed foodstuff. However, not only the eating habits, but as well the grocery shopping and eating places change. The consumers increasingly use to have a meal outside the home.

An individual's characteristics determining his/her food consumption choices are, for example, level of incomes per household member, and knowledge and awareness about the composition of foodstuff, its impact on health, recognition of markings. These are the considerations related to the individual's value system, role of the status, for instance, when buying expensive liquor, exclusive foodstuff, as well as ethical considerations regarding consumption of the animal food products.

Food seasonality still has a significant role in the food consumption. Nevertheless, the product price, and views of a healthy lifestyle, including a healthy diet has to be considered as the key factors in the foodstuff choices (Eglite, 2010).

Changes in the consumer behaviour involve not only financial aspect, but also phases of the life-cycle, and personal development.

There are still strong traditions of cultivating food for personal use, and preserving it for the winter. In rural areas, $18 \%$ of consumed foodstuff is cultivated and produced by the consumers themselves. In Latvia, there still are households using in their daily nutrition agricultural products - vegetables, dairy products, meat, fish caught, or wild animals hunted, that is, products in kind - either produced by themselves, or received from relatives, friends for free. (Majsaimniecibu..., 2016) These consumer traditions of cultivating food give us information of local food characteristic and importance criteria what mean local food.

In the empirical research, significance of the local foodstuff in consumption of the modern consumers was explored. The results encourage new ideas requiring in- depth research to approve the identified probabilities. The respondents have provided their replies on frequency of the purchase of the local foodstuff (Fig. 1).

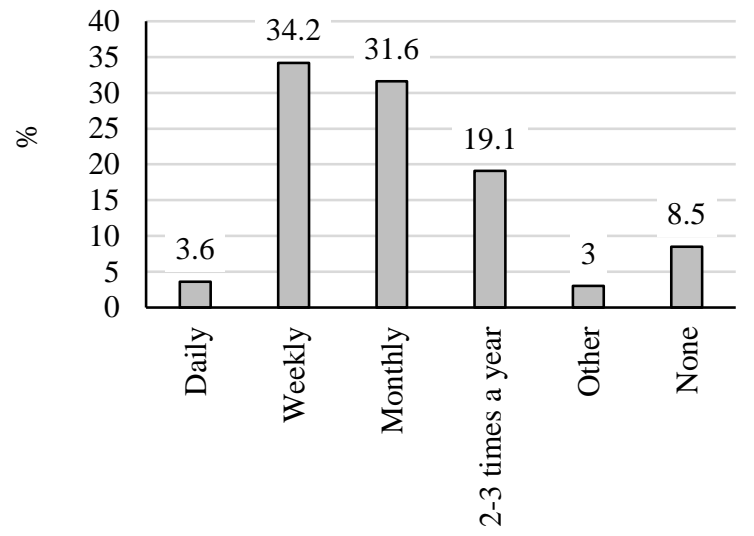

Figure 1. Frequency of buying the food from the local domestic producers

$34.2 \%$ of the respondents purchase the domestic food on a weekly basis, $31.6 \%$ - monthly. It suggests that the domestic food is in demand. Since the vast majority of the respondents purchase the local foodstuff in the domestic producers' markets, it provides an explanation of shopping frequency (Fig. 2).

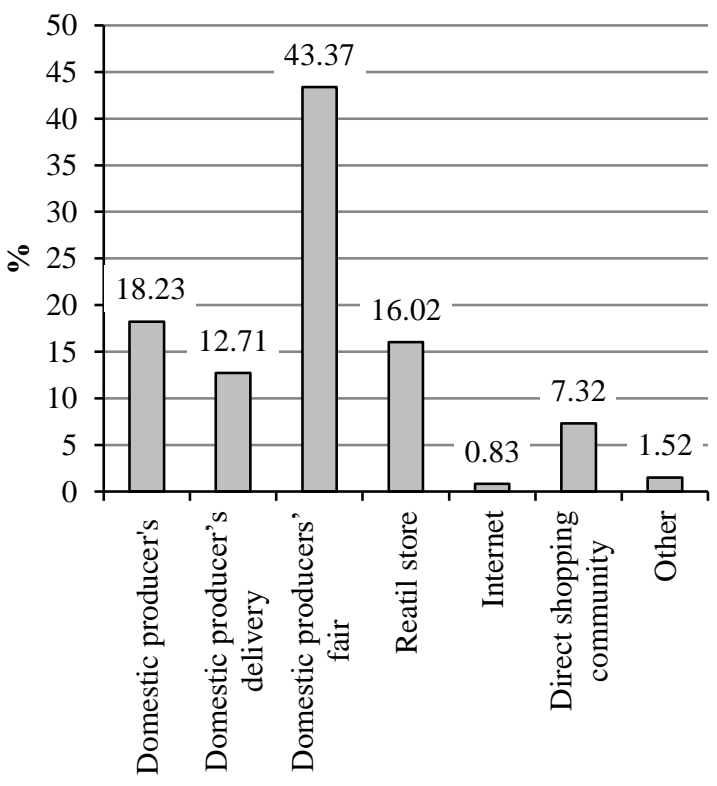

Figure 2. Places of buying the local domestic food

The Figure 2 shows that the most popular local domestic food acquisition place is the domestic producers' fair. Fairs usually take place on weekends or before holidays. People have more free time or a desire to buy something different to serve on a festive table. Also, many local municipalities of the Latgale region, considering the local economic development, take initiative and organize the domestic producers' fairs on the certain days of month, informing the local community (e.g. the association "LEARN" at the Rezekne municipality). Fairs are becoming increasingly popular, as evidenced by engagement of the supermarket chains "Rimi" and 
"Maxima" as the domestic producers' are allowed organising their fairs in the parking lots of the mentioned supermarkets.

$57.68 \%$ of the respondents during a visit to the domestic producers' fair spend in average 6-15 EUR, 20.18\% 16-30 EUR, $17.54 \%$-up to 5 EUR, and $4.61 \%$ - above 31 EUR. Level of spending is determined by the level of income and the average price of foodstuff (Table 1).

Table 1

Spending on purchases in relation to income level, \%

\begin{tabular}{lcccc}
\hline \multirow{2}{*}{ Incomes } & \multicolumn{4}{c}{ Spending on purchases } \\
\cline { 2 - 5 } & $\begin{array}{c}\text { Up to 5 } \\
\text { EUR }\end{array}$ & $\begin{array}{c}\text { 6-15 } \\
\text { EUR }\end{array}$ & $\begin{array}{c}\text { 16-30 } \\
\text { EUR }\end{array}$ & $\begin{array}{c}\text { 31 EUR } \\
\text { and more }\end{array}$ \\
\hline Up to 400 EUR & 28.26 & 58.70 & 10.87 & 2.17 \\
401 -600 EUR & 14.88 & 59.50 & 19.01 & 6.61 \\
601 - 800 EUR & 11.11 & 61.62 & 24.24 & 3.03 \\
801 EUR and & 17.16 & 52.24 & 24.63 & 5.97 \\
more & & & \\
\hline
\end{tabular}

The Table 1 shows that the respondents with lower incomes spend relatively less money in the domestic producers' fair. Between spending on purchase and income level have close positive correlation (0.87) with significant level 95\%. If income levels decrease also decrease spending on purchase. There are a number of probabilities that could justify the above mentioned:

$\circ$ the domestic food is relatively more expensive than the foodstuff in supermarkets (Fig. 4), and the people with lower income can channel a relatively smaller share of their income for the food;

- more than 31 EUR is spent by a relatively small number of the respondents because period of use of the local domestic food is short.

Every consumer has its own motivation and reasons to buy the local food products (Fig. 3.).

The respondents' most important motivation is awareness that the local product is being acquired (53\%), and it also is an opportunity to support the local producers $(34.5 \%)$. These responses confirm the importance of the local products in the consumption of the modern consumers. $44.8 \%$ of the respondents believe that the local food quality and choice is much higher. $40.7 \%$ of the respondents consider the significance of eco-friendly products. Often, the local foods are associated with eco-friendly products. The respondents' replies encourage ideas for the further indepth research that should be focused on evaluation of the consumer behaviour in a particular region.

One of the key aspects affecting the buying motivation is level of education (Table 2).

The level of education contributes to the global way of thinking, for instance, by supporting the local economy, not only receiving direct personal benefits. The respondents with a higher level of education have a wider range of vision and knowledge that may affect the awareness of the product's nutritional value healthiness, place of origin, usefulness.

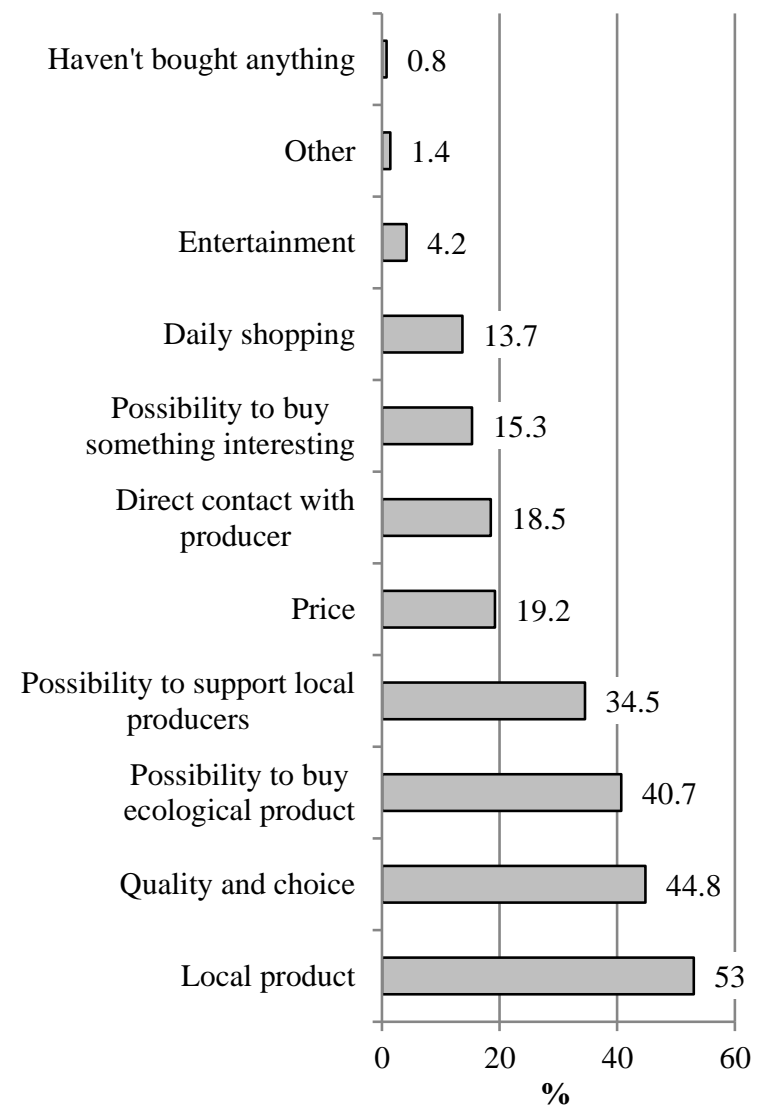

Figure 3. Motivation to buy local domestic producers' foodstuff

Table 2

Respondents' motivation to buy the local domestic food depending on the level of education

\begin{tabular}{|c|c|c|c|c|}
\hline \multirow[t]{2}{*}{ Motivation } & \multicolumn{4}{|c|}{ Level of education } \\
\hline & 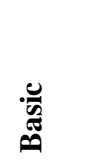 & 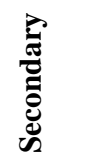 & 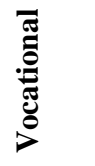 & 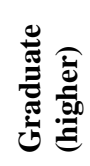 \\
\hline Daily shopping & 4.11 & 6.39 & 9.27 & 3.98 \\
\hline $\begin{array}{l}\text { Possibility to buy eco- } \\
\text { friendly products* }\end{array}$ & 17.81 & 14.89 & 16.10 & 16.54 \\
\hline Local product & 17.81 & 21.88 & 24.39 & 20.06 \\
\hline Quality and choice & 13.70 & 21.58 & 18.54 & 16.07 \\
\hline Price & 10.96 & 10.94 & 8.29 & 5.21 \\
\hline $\begin{array}{l}\text { Direct contact with } \\
\text { producer }\end{array}$ & 12.33 & 5.47 & 7.81 & 7.50 \\
\hline $\begin{array}{l}\text { Possibility to support } \\
\text { local producers }\end{array}$ & 10.96 & 11.85 & 9.27 & 16.39 \\
\hline Entertainment & 1.37 & 1.82 & 2.44 & 1.23 \\
\hline $\begin{array}{l}\text { Possibility to buy } \\
\text { something interesting }\end{array}$ & 9.59 & 4.86 & 3.42 & 7.20 \\
\hline $\begin{array}{l}\text { Haven't } \quad \text { bought } \\
\text { anything }\end{array}$ & 1.37 & - & - & 5.05 \\
\hline Other & - & 0.30 & 0.49 & 0.77 \\
\hline
\end{tabular}




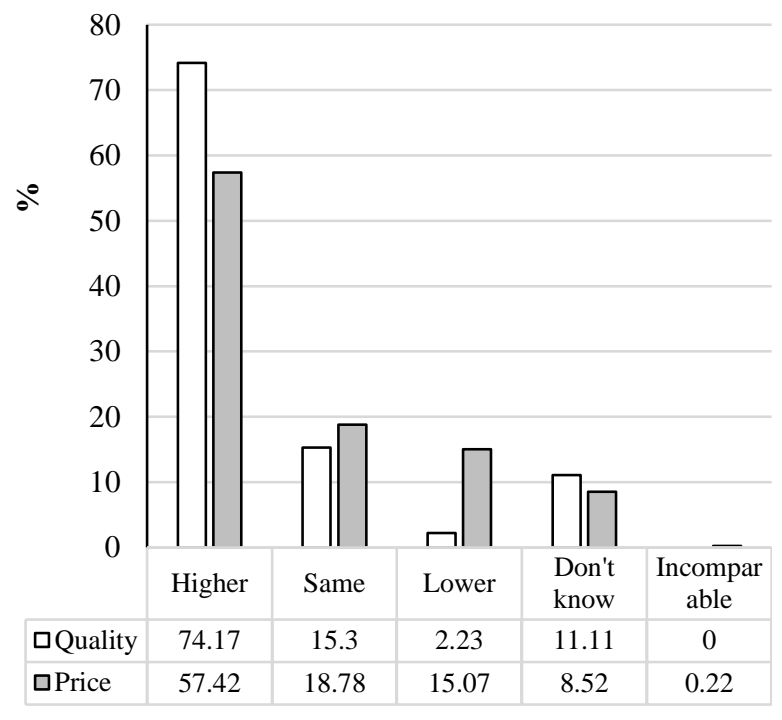

Figure 4. Comparison of the local domestic producers' product quality and prices with the supermarkets'

Product quality consumers understand as the characteristics of a given product or quality score what make features of a set of food (appearance, colour, odour, nutritional value, origin of the product, ease of preparation, safety), what provides the consumer needs and it practical validity (Prasibas partikas kvalitates..., 2014).

Majority $(74.17 \%)$ of the respondents believe that quality of the domestic food is higher than quality of the products sold in supermarkets (Fig. 4). 93.65\% of the respondents are satisfied with the quality of the local domestic food, evidencing that the local domestic food is of high quality and, in compliance with this criterion, it is competitive.

In recent years, short food supply chains (direct selling: farmer $\longrightarrow$ buyer), the farmers' markets and fairs, and the slow food movement gradually develop. As well the organic food becomes more available, though it is still relatively more expensive, therefor its consumption is limited (Silicka, Litavniece, 2016). This is evidenced by the survey data as well, since $57.42 \%$ of the respondents believe that prices of the domestic food are higher than of the products sold in supermarkets.

Table 3

Evaluation of the local domestic food prices compared to the supermarket prices, depending on the income level of the respondents

\begin{tabular}{lcccc}
\hline Criteria & Higher & Same & Lower & $\begin{array}{l}\text { Don't } \\
\text { know }\end{array}$ \\
\hline Up to 400 EUR & 18.15 & 24.71 & 18.18 & 32.43 \\
401-600 EUR & 25.48 & 30.59 & 31.82 & 21.62 \\
601-800 EUR & 20.85 & 20.0 & 30.30 & 18.92 \\
$\begin{array}{l}\text { 801 EUR and } \\
\text { more }\end{array}$ & 35.52 & 24.71 & 19.79 & 27.03 \\
\hline
\end{tabular}

However, comparing the estimates by the respondents according to their total family income, it is observable (See Table 3), that the respondents having higher income believe that price of the local domestic food is higher.

The survey results foster debate and encourage the need for in-depth study. There is a likeliness that the respondents with lower income primarily choose discount products, but people with higher incomes are not ready to pay a higher price, unless the quality criteria of the product do not comply with.

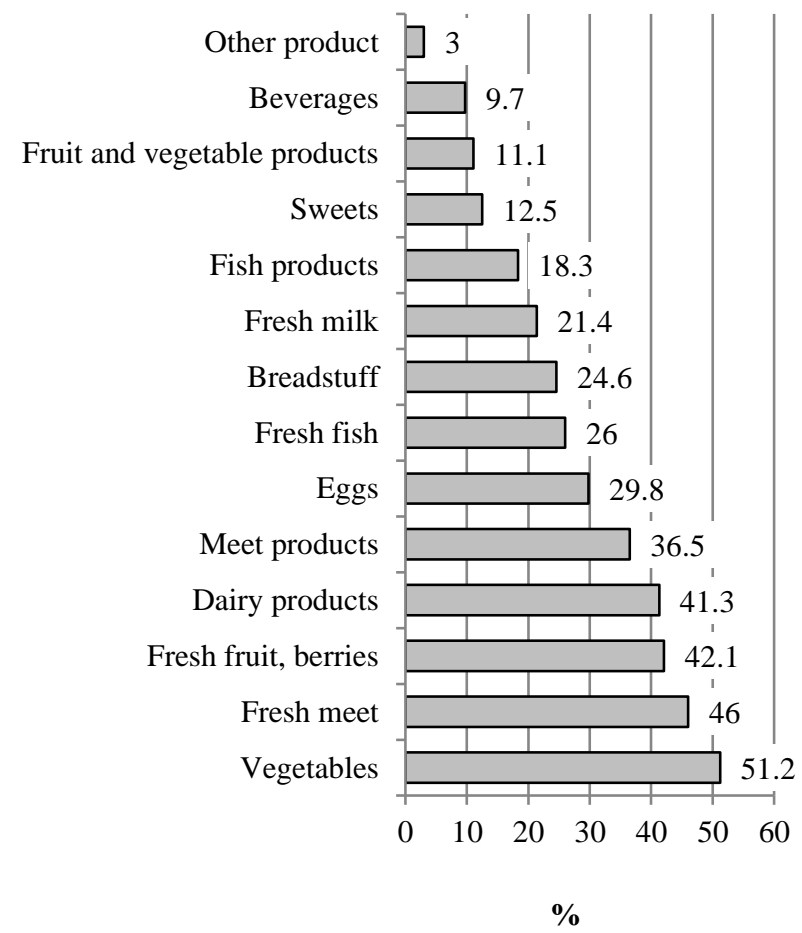

Figure 5. Types of the domestic food

One of the most common types of products purchased at the local domestic producers' (Fig. 5) are vegetables $(51.25 \%)$.

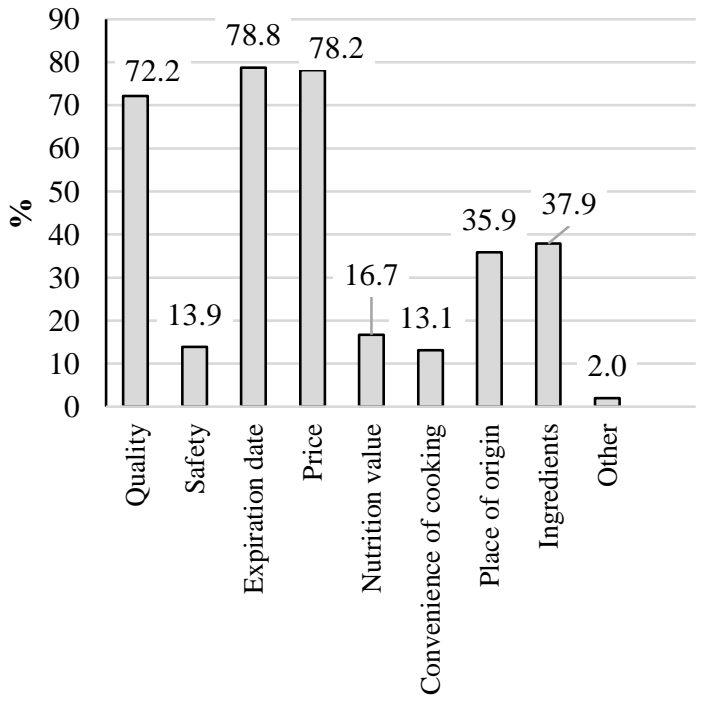

Figure 6. Characteristics the respondents pay attention to when purchasing the local food products

More than $70 \%$ of the respondents believe that the quality, expiration date, and price are the most important 
characteristics of the product to be paid attention to when purchasing the product.

\section{Conclusions}

Modern consumers pay attention to origin of the product. Consumer behaviour impacts education and income level. Higher income and education level provide consumers thinking from the global to the local. According it people more think what they buy and what they eat and for these people local food is significant in their consumption.

Often, in perception of the consumers, the local food is one of the aspects of healthy food (it can be concluded from the survey conducted).

In the result of the empirical research, the authors have concluded that, to evaluate the data obtained, it is necessary to carry out the in-depth research on the choices of the local foodstuff and evaluation criteria in the view of consumers.

\section{References}

1. Abate G. (2008) Local Food Economies: Driving Forces, Challenges, and Future Prospects. Journal of Hunger \& Environmental Nutrition, Vol. 3, p. 384-399.

2. Anderson M.D. (2007) The Case for Local and Regional Food Marketing. Farm and Food Policy Project. [accessed on 12.03.2016.]. Available at: http://www.farmlandinfo.org/case-local-and-regionalfood-marketing.

3. Aurier P., Fort F., Sirieix L. (2005) Exploring Terroir Product Meanings for the Consumer. Anthropology of Food. [accessed on 12.03.2016.]. Available at: http://aof.revues.org/index187.html

4. Barham E. (2003) Translating terroir: the global challenge of french AOC labeling. Journal of Rural Studies, Vol. 19, p. 127-138.

5. Best M.J., Wolfe K.L. (2009) A profile of local dairy consumers in the southeast and the potential for dairies to market value-added products locally. Journal of Food Distribution Research, Vol. 40, p. 22-31.

6. Bolen A. (2016) Seven characteristics of the modern consumer. [accessed on 09.12.2016.]. Available: https://www.sas.com/en_us/insights/articles/marketing/ modern-consumer.html

7. Brown C., Miller S. (2008) The impact of local markets: A review of research on farmers' markets and community supported agriculture. American Journal of Agricultural Economics, Vol. 90, p. 1296-1302.

8. Carpio C.E., Isengildina-Massa O. (2009) Consumer sillingness to pay for locally grown products: The case of South Carolina. Agribusiness, Vol. 25, p. 412-426.

9. Centrala Statistikas parvalde. [accessed on 13.12.2016]. Available at: http://data.csb.gov.lv/pxweb/lv/Sociala/ Sociala_ikgad_iedz_iedzskaits/IS0010.px/table/table ViewLayout $2 /$ ?rxid=09cbdccf-2334-4466-bdf70051bad1decd
10. Eglīte A. (2010) Patērētāja uzvedības izmaiṇas mūsdienu apstākḷos. Economic Science for Rural Development Conference proceedings, Vol. 23, p. 151-155.

11. EK, 2011. Videi draudzìgs "iepirkums"! Videi draudzīga valsts iepirkuma rokasgrāmata. Luksemburga, Eiropas Kopienu Oficiālo publikāciju birojs.[accessed on 12.12.2016]. Available at: http://ec.europa.eu/environment/gpp/pdf/handbook.pdf

12. Futamura T. (2007) Made in Kentucky: The meaning of 'local' food products in Kentucky's farmers' markets. The Japanese Journal of American Studies, Vol. 18, p. 209-227.

13. Hughes D.W., Eades D., Robinson K., Carpio C., Isengildina O., Brown C. (2007) What is the deal with local food systems: Or, local food systems from a regional perspective, Working Paper 11-2007-01, Clemson University, Clemson, SC.

14. Jemeljanovs A. (red.) (2013) Latvijas iedzīvotāju pārtikā lietojamās gal̦as raksturojums. LLU Biotehnologijas un veterinārmedicīnas zinātniskais institūts, „Sigra”. 350 lpp.

15. Litavniece L., Silicka I. (2016) Evaluation of local identity food in the development of gastronomic tourism in Rezekne city and county. In: Proceedings of the International Scientific Conference. SOCIETY. INTEGRATION. EDUCATION. Vol.IV, May 27th-28th, 2016. Rezekne, Rezeknes Academy of Technologies, p. 355-364.

16. Mājsaimniecību patēriña izdevumi palielinājušies par 5,4\% (2016). [accessed on 09.01.2017.]. Available at: http://www.csb.gov.lv/notikumi/majsaimniecibupaterina-izdevumi-palielinajusies-par-54-43403.html

17. Oort F. (2005) Using structural equation modeling to detect response shifts and true change. Quality of Life Research, Vol. 14(3), p. 587-598.

18. Praude V. (2011) Mārketings. Teorija un prakse. 2.grāmata. Trešais pārstrādātais un papildinājums izdevums. SIA "Burtene"

19. Prasības pārtikas kvalitātes shēmām to ieviešanas, darbības, uzraudzības un kontroles kārtība MK not. 461 no 12.08.2014.

20. Raosoft Inc. (2004) Sample size calculator [accessed on: 19.12.2016]. Available at: http://www.raosoft.com/samplesize.html

21. Sabiedrības veselības pamatnostādnes 2014.2020.gadam. [accessed on: 19.12.2016]. Available at: http://polsis.mk.gov.lv/documents/4965

22. Testa F., Iraldo F., Frey M., Daddi T. (2012) What factors influence the uptake of Green public procurement practices? New evidence from an Italian survey. Ecological Economics, Vol. 82, p. 88-96.

23. Vaarst M., Hovi M. (2004) Organic livestock production and food quality: a review of current status and future challenges. In: Proceedings of the 2nd SAFO Workshop. Witzenhausen, Germany, 25 - 27 March 2004, p. 7-15. 24. Ziņojums par Latvijas Tautsaimniecības attīstîbu (2016). [accessed on 09.01.2017.]. Available at: https://www.em.gov.lv/files/tautsaimniecibas_attistiba/2 016_jun.pdf 